\title{
Preserving Farmland on the Urban Fringe: A Literature Review on Land Policies in Developed Countries
}

\author{
Coline Perrin ${ }^{1, *(1)}$, Camille Clément ${ }^{1}$, Romain Melot $^{2}$ and Brigitte Nougarèdes ${ }^{1}$ (C) \\ 1 INRAE (French National Research Institute for Agriculture, Food and Environment), UMR Innovation, \\ CIRAD, INRAE, Institut Agro, University of Montpellier, 2 Place Pierre Viala, bât. 27, CEDEX 02, \\ 34060 Montpellier, France; camilleleilaclement@gmail.com (C.C.); brigitte.nougaredes@inrae.fr (B.N.) \\ 2 INRAE (French National Research Institute for Agriculture, Food and Environment), UMR SADAPT, \\ Université Paris Saclay, AgroParisTech, 16 rue Claude Bernard, 75005 Paris, France; romain.melot@inrae.fr \\ * Correspondence: coline.perrin@inrae.fr
}

Received: 11 June 2020; Accepted: 6 July 2020; Published: 9 July 2020

\begin{abstract}
This paper reviews the recent literature dealing with farmland protection (FP) policies in developed countries from a planning perspective, with a specific focus on the Mediterranean region. It provides coverage of French language papers that may have been omitted in previous reviews. While the Mediterranean is often pointed out as a region with acute challenges related to food security and a lack of effective planning policies, the literature underlines that issues related to FP policies are similar across the world. Hence, this review may bring valuable insights for more sustainable management of farmland on the urban fringe. It maps several interesting areas of research concerning the often implicit and disparate rationales of FP policies as well as the barriers and potential avenues for improvement for FP. It highlights that FP cannot rely merely on transferring policy tools that have proven successful elsewhere. It also reveals that land policies do not always take into account the specific needs of farming systems, as they often focus on land rather than on agriculture. Further research is thus needed to reveal the interaction over time between the use of certain FP tools and the unique local features of urban fringe agriculture. This review may be of interest to students and scholars, but also to practitioners, policy makers and local groups looking for innovative, more flexible or locally suited farmland protection programs.
\end{abstract}

Keywords: farmland protection; peri-urban agriculture; land-use planning

\section{Introduction}

Farmland preservation is a longstanding challenge on the urban fringe [1,2]. In the last two decades, farmland loss has increasingly become a worldwide matter of concern, both for environmental and food security reasons [3]. In all developed countries, as well as in some developing and emerging countries, there is debate about how farmland conversion to urban uses should be governed [4].

Extensive scientific literature is devoted to the issue of farmland preservation on the urban fringe, which involves planners, agricultural economists, geographers, and other social scientists. Scholars have provided a good overview of the range of land policy instruments tested around the world. The tool box features land-use regulation, acquisition (or transfer) of land or development rights, and incentive-based approaches [5]. Law scholars have shown that their preferential use varies according to the country [6]. Depending on local property rights and land-use regulations, the same tool (e.g., zoning) may be used for different planning practices in the United States and Europe [7].

In this paper, it is not our objective to describe and assess farmland protection (FP) techniques, as some scholars have already provided comparative evaluations [8]. Our focus on planning literature 
aims to draw lessons from policy alternatives and local initiatives with regard to the way they take farming into account by answering the following questions: what are the rationales for FP? What are the main barriers and challenges hampering FP programs' efficacy and the inclusion of farming issues in land policies? Can we point towards future policy directions or research avenues? How could FP policies better maintain farming while meeting public preferences on the urban fringe?

Our methodological approach consists of a review of scientific papers published in English and French on FP in the face of urbanization, with a particular focus on the Mediterranean region. While such a topic is multidisciplinary by nature, we concentrate on qualitative studies conducted in planning, geography, sociology and political science. Our review cites a few key economics references, but does not cover the extensive existing literature on this topic in agricultural and land-use economics. While farmland preservation has recently become a major issue in emerging countries, especially in China $[9,10]$, we consider that the issue of FP in such countries would deserve separate reviews in order to take into account their specific property regimes and land-use regulations. Hence, we narrowed our literature review to developed countries and to the Mediterranean region, thanks to our access to the French-language literature and with a view to this paper's inclusion in the special issue of the Land journal on "Land and Farming System Dynamics on the Mediterranean Basin: From Global to Local Case Studies".

Farmland preservation is particularly urgent in the Mediterranean; we identified research on this topic in all European countries in the region, as well as in the Maghreb, Lebanon and in Israel. In the last two decades, the Mediterranean has undergone an intense urbanization process, mainly at the expense of prime agricultural land, since cities are historically located in the most fertile coastal plains [11] and tourist activities have increased urban sprawl on the coasts [12,13]. Land tenure varies across regions. Around cities, it may be very fragmented amongst private smallholders or owned by a few large landowners that are public, religious (habous or waqf lands) or private [14-16]. Mediterranean farming systems are under particular pressure from climate change and soil degradation, increasing the challenges related to food and water security [17]. Farming is also jeopardized by the risk of land abandonment, which stems from the rural exodus as well as from the pressure to convert farmland for urban uses in peri-urban areas $[18,19]$. In this context, Mediterranean peri-urban agro-ecosystems show contrasting dynamics, ranging from decline to adaptation to urban demands [20,21]. Diversification activities, both agricultural (social farming, educational farms) and non-agricultural (tourism, energy), as well as the supply of services to the cities, are increasing on peri-urban farms, at least in Northern Mediterranean countries. They facilitate the integration of agricultural producers into short supply chains. However, while they appear in some cases as a rewarding strategy and a successful response to urban pressure, in other cases they can seem a "last attempt" to adapt before abandonment [19]. Such diversification activities often raise a need for specific building rights to implement the multiple 'farm to fork' steps requiring more than the usual farm buildings for storage of products or machines and shelter for animals. For example, farmers seeking better integration into local supply chains may claim building rights related to on-farm processing and conditioning of products, distribution hubs and on-farm shops or accommodation for agri-tourism. In peri-urban areas, planning authorities thus have to arbitrate between different interests, finding innovative ways to preserve farmland from further urban sprawl, while considering claims for the right to build structures needed for multifunctional farming projects $[12,15]$. This brings into question the efficacy of local policies dedicated to FP on the urban fringe [22].

The results of this literature review on developed countries are presented in three sections: we first give insights into the rationales for FP, then into the barriers to FP and finally into the avenues of improvement for public policy and future research. Before proceeding, we detail our material and methods. 


\section{Materials and Methods}

This literature review covers 104 papers from 22 journals. This corpus was built on a combination of two methods.

First, we searched the SCOPUS and WOS databases for all papers dealing with farmland preservation/protection in the face of urbanization. The words "protection" and "preservation" are both relevant. "Preservation" is more frequent where tools are incentive-based, while "protection" is used where the approach is regulatory. However, some papers use these terms interchangeably, sometimes even employing the term "conservation". We thus used the keywords "protection", "conservation", and "preservation" in association with "farmland" and "urban"1. Taking into account that some papers were identified both in WOS and SCOPUS, this query resulted in a corpus of 200 unique references from 89 scientific journals, 60 of which contained only one reference. China (with 88 papers) and the United States (with 64 papers) stood out as the prime areas studied. This corpus omitted some papers that we considered important and counted only 12 papers on the Mediterranean region.

Second, we conducted a manual search of 30 journals: the 7 English-speaking journals with more than 5 references in this WOS-SCOPUS corpus ${ }^{2}$ and 23 other journals $\left(15\right.$ in French ${ }^{3}$ and 8 in English ${ }^{4}$ ) from the field of geography and planning. We scanned all issues of these journals since 1995, reading the titles, keywords and some abstracts, and added 141 relevant papers to our corpus (Figure 1).

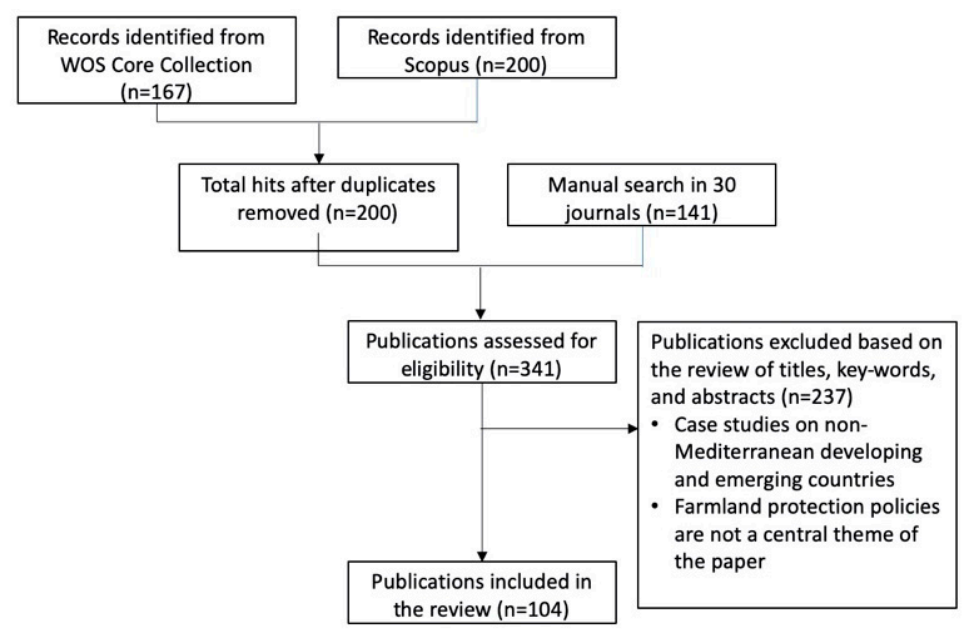

Figure 1. Flow diagram of the selection process.

1 In the SCOPUS database, we found 200 references through the query: (TITLE-ABS-KEY ("farmland preservation" OR "preservation of farmland" OR "farmland conservation" OR "conservation of farmland" OR "farmland protection" OR "protection of farmland") AND TITLE-ABS-KEY (*urban*)) AND SUBJAREA (mult OR agri OR bioc OR immu OR neur OR phar OR mult OR arts OR busi OR deci OR econ OR psyc OR soci). In the WOS database, we found in May 2020167 references through the query: (TS $=($ "Farmland preservation" or "preservation of farmland") AND TS $=($ *urban*)) OR (TS $=($ "farmland protection" or "protection of farmland") AND TS $=($ *urban*) $)$ OR (TS $=($ "farmland conservation" or "conservation of farmland") AND TS $=\left({ }^{*}\right.$ urban $\left.\left.^{*}\right)\right)$. Indexes $=$ SCI-EXPANDED, SSCI Timespan = All years.

2 The journals with 5 papers or more in the WOS-SCOPUS query were Land Use Policy (32 papers), Transactions of the Chinese Society of Agricultural Engineering (19 papers in Chinese, not included in our analysis), Sustainability (19), Journal of Soil and Water Conservation (12), Journal of the American Planning Association (7), Landscape and Urban Planning (7), Habitat International (7), and Journal of Rural Studies (5).

3 The selection of French journals was based on their ranking by the French High Council for the Evaluation of Research and Higher Education (HCERES) and their interest in the Mediterranean region: Economie rurale, Revue d'économie régionale et urbaine, Norois, Géocarrefour, Développement durable et territoire, Méditerranée, Espaces et sociétés, VertigO-la revue électronique en sciences de l'environnement, Sud-Ouest européen, Annales de géographie, Géographie, économie et société, Etudes Rurales, L'Espace géographique, Options Méditerranéennes, and Cahiers Agriculture.

4 Journal of Planning Literature, Agriculture and Human Values, Urban Studies, Environment and Planning C: Government and Policy, Environment and Planning D: Society and Space, Geoforum, Journal of Urban Planning and Development and Geographical Research. 
From this corpus of 341 papers, we excluded those on non-Mediterranean developing and emerging countries and those presenting only spatial analyses of farmland conversion without considering farmland protection mechanisms. We looked specifically for papers on the Mediterranean region and on public policies. We sorted the remaining papers into a mind-map diagram according to their focus on the following topics: the rationales for FP policies, the diversity of tools and stakeholders in farmland preservation policies, the importance of spatial, social and political contexts for understanding farmland preservation mechanisms and the impacts of FP. Figure 2 provides an overview of the categories and sub-categories identified through this review of titles, key-words and abstracts, in a mind-map diagram.

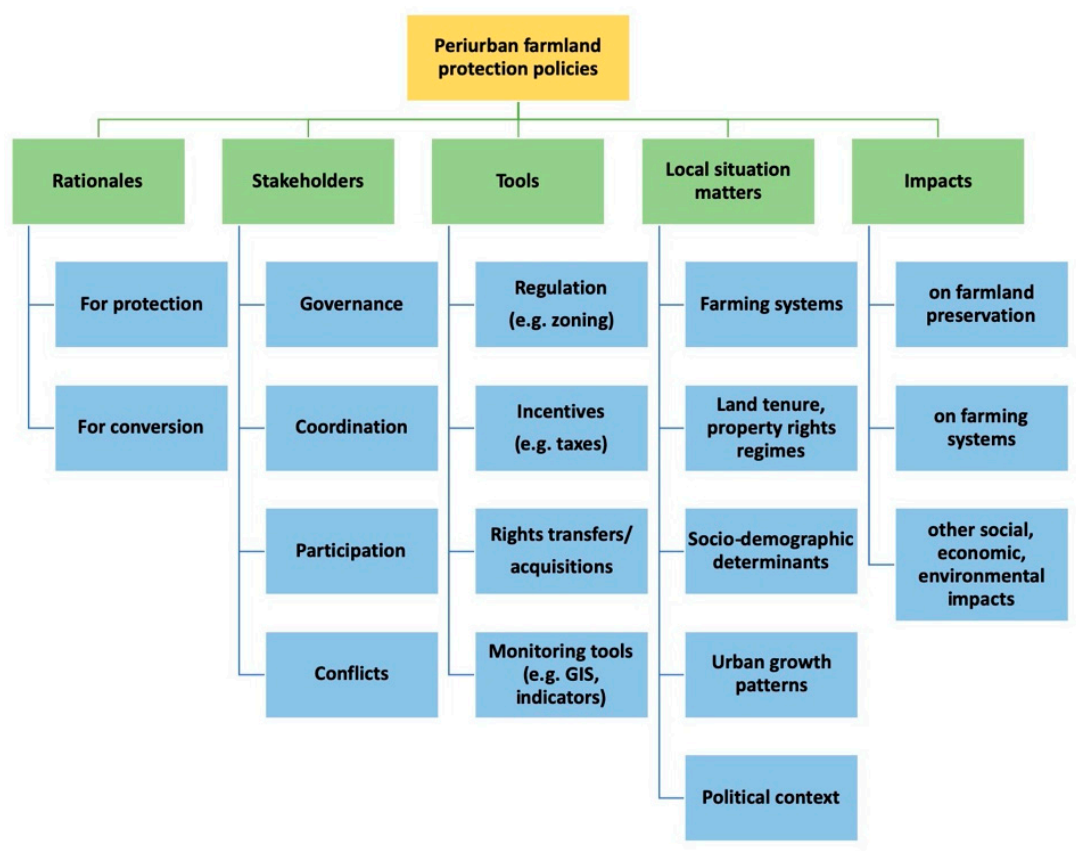

Figure 2. Mind-map diagram of the topics identified through the review of titles, key-words and abstracts.

Based on these two corpora built on a query in WOS-SCOPUS and a manual search, as well as on this mind-map diagram, we selected 104 papers to read. The main journal is Land Use Policy, with 45 papers, followed by Landscape and Urban Planning, with 18 papers. The remaining 41 papers are distributed among 20 journals, 12 in French and 8 in English. To proceed with reading and comparative analysis of the papers, we developed a standardized form to be filled with the main information we would collect from the papers, namely: the scale of analysis, the location of the case study, the FP instruments, the main actors, the factors for the success or failure of FP, the field or discipline, the research question(s) and method(s), and the avenues for future research. The results of this literature review shed light on the rationales behind FP, on the barriers to effective FP and on avenues of improvement for research and public policies.

\section{Differing Rationales for Farmland Protection: Maintaining Farming is Not Always the Priority}

Farmland preservation is often presented as an unquestionable necessity. However, since the 1970s, research has raised the questions as to why and for whom farmland should be preserved, uncovering diverse rationales [23]. Today, there is still no consensus about why farmland preservation is important.

\subsection{Implicit, Changing, or Disparate Rationales for Farmland Protection}

FP objectives are often not explicit [24]. The ambiguity lies primarily in policy framing. Agriculture itself may be overlooked or neglected because there are other overarching priorities: on one hand, social housing and employment issues may legitimize urban development, for instance in the Maghreb [20] 
and Israel [25] and, on the other hand, environment or landscape preservation, rather than agriculture, may legitimize urban containment and open space protection in public preferences [26-28]. In triangular planning models that do oppose agriculture, nature and urban development [29], "nature and agriculture often stand in opposition in the quest for land" [30]. FP may also be conceived as an interim stage before projected urban development, as mentioned in Japan [31] or Israel [32].

Where FP is an explicit long-term priority, the rationales that legitimize such policies vary. Objectives for a given farmland or open-space preservation program may change over time and space [33]. For example, Amati and Yokohari [34] observe that contiguous municipalities assign different functions to the London Green Belt. Feitelson [35] illustrates the shifting rationales of the FP program in Israel since the 1960s: the program has moved from productionist arguments (farmland as a resource for food or as an economic sector) to an urban-centered perspective (farmland preservation as a growth management tool to regulate urban sprawl) and environmentalist arguments (concerns over loss of positive externalities). By 1977, Gardner [23], albeit skeptical about removing land allocation from market mechanisms, had already outlined four potential benefits that could reinforce the public legitimacy of FP policies: food security, economic benefits derived from a viable agricultural industry, open space and environmental amenities, and sounder urban development.

While there is no evidence that such varying or combined rationales hinder FP programs' efficacy, scholars have underlined the heterogeneous nature of the stakeholders who support FP. In Canada, Spaling and Wood [36] identify disparate ethical views about FP and "anomalous alliances among interest groups with seemingly different land policy objectives". Similarly, Bunce [37] examines the public discourse of the North American FP movement and the ideologies underpinning it over a 30 year period. He shows how the policy agenda has largely been controlled by non-farming interests, influenced by environmentalist and agrarian ideologies with alternating visions of farming for food production, ecological conservation, or rural authenticity. In the case of Israel too, "the rationales are used to cobble a coalition of planners, environmentalists, farmers, urbanites and exurbanites, against a powerful development coalition" [35].

So whom, in the end, is farmland being preserved for? In some programs, farmers formed the original political support behind FP and were included in the process of elaboration [2]. In the state of Oregon, some farmers still support the programs, while others count among the landowners bristling for change and claiming compensation for the foregone increases in land prices in the 2000s [38]. In other programs, residents' quality of life is the main driver and public focus is on farmland, rather than on farming. In such cases, scholars warn that "without expanding its focus beyond farmland to encompass farming and farmers, the movement risks losing both integrity and effectiveness" [39]. Farmers may be cast in the role of guarantors of food supply and stewards of landscape, rural heritage and community values [40].

Such combined rationales appear in Mediterranean countries and elsewhere. From a critical perspective, research on FP rationales reveals who defines and controls the FP agenda and whose interests it really serves. It clarifies why FP remains a contentious policy issue.

\subsection{Farmland Protection as a Contentious Policy Issue}

On the urban fringe, many conflicts are related to FP. Since the 1970s, scholars have highlighted equity implications of FP instruments [23,41-43]. Conflicts first place in opposition local authorities implementing the FP policies and landowners wishing to lock in the land value increase [44]. Conflicts are also linked to place-based collective efforts to prevent the negative impacts of urbanization on agrarian landscapes. In such cases, FP often appears to be "window dressing" for other goals [39] that are not directly linked to agricultural interests. In the Greater Paris Region (France), urbanization projects are contested mainly by opponents of farmland conversion. Some residents seem more concerned about illegal occupations of fallow land (especially by gypsy communities) than about the abandonment of farming itself [45]. In Swiss villages, residents protest against dense urban developments by denouncing the visual nuisance and the loss of landscape [46]. Similarly, Pacione [47] 
points out that fear of increasing road traffic is the overwhelming argument put forward by residents in the public consultation proceedings for the preservation of the Glasgow greenbelt. Hence, protection of local amenities is a key argument when residents and associations get involved in FP movements.

In the Mediterranean, land-use conflicts over farmland are increased by the scarcity of the resource, as farming is often in intense competition with both residential and touristic uses. The Huerta de Valencia is a good example of such a situation, as its peri-urban agricultural systems are also valuable as an important cultural, natural and landscape heritage [48]. On the French island of Corsica as well, many conflicts arose over the implementation of land-use restrictions on the coast [49].

\subsection{Taking Differing Rationales into Account in Policy Design}

Research on rationales for FP has practical policy implications. Revealing that heterogeneous coalitions of stakeholders and disparate farmland ethics are involved in land issues on the urban fringe may suggest policy options and decision-making tools that reduce land-use conflicts [36]. Place attachment is often identified as a strong motivation for FP [28,50]. In addition, peri-urban agricultural landscapes are valued by the urban public for a range of functions not typically included in land-use policies [51,52]. This knowledge can assist policy makers in prioritizing which areas to preserve. Using focus groups and surveys of residents to identify public preference, Kline and Wichelns [53] show that FP programs should consider not only farmland or farming (or prime farmland) but also the farming style (e.g., environmentally friendly farming). In comparing the mission statements of 130 land trusts engaged in FP, Brinkley [54] similarly finds "uniform preferences for parcels that provide ecosystemic services, wildlife habitat, viewsheds, local heritage, and agricultural productivity". Kerselaers et al. [55] provide a review of the diversity of criteria that are mentioned to determine farmland preservation priorities. In the case of the Huerta de Valencia, Marques-Perez and Segura [48] stress that integrating people in the decision-making process is fundamental for conveying the preferences of citizens and preventing conflicts.

The literature on rationales therefore highlights a public focus on open space, landscapes and the environment, beyond farming. Mixed policy goals and conflicting interests, both among stakeholders and among farmers themselves, are part of these underlying rationales. The confusion between farmland and farming may be the first barrier to the success of FP programs.

\section{Barriers and Challenges for Farmland Protection Programs to be Effective and Take Farming into Account}

FP programs' implementation often encounters the same problems: the lack of awareness of how farms and farming systems operate; the lack of adequate enforcement by, and coordination between, public stakeholders; and the failure to take into account the contradictory time frames of the parties involved as well as the specific features of the local context.

\subsection{Lack of Awareness of How Peri-Urban Farms and Farming Systems Operate}

Preservation and commodity programs may work against one another on the suburban fringe [56].

Agricultural policies, driven in the US by the state and in the Mediterranean by national governments and the European Union (EU) use regulations and incentives to tell farmers what and how to farm. They may be decisive in maintaining farming (e.g., through income support or through direct payments to farmers) in contexts of high external pressure for non-agricultural use of the farmland. However, such policies do not always support peri-urban farms. For instance, Piorr et al. [57] explain that the EU Common Agricultural Policy does not recognize the specific needs of urban and periurban agriculture due to their particular characteristics in terms of actors, scale, diversity and location in urban areas and their surroundings. Urban and peri-urban farms were even excluded from Rural Development Policies until very recently.

Similarly, FP programs sometimes show a lack of awareness of how farms and farming systems work, especially when they are designed by urban stakeholders without sufficient knowledge of 
agriculture. Zoning may show spatial inconsistency. When prime productive farmlands are located close to urban areas and face higher pressure, they may be less protected, as in the South of France [58]. In Wisconsin, for instance, exclusive agricultural zoning is more likely to be adopted in municipalities located outside conurbations [59]. Moreover, when strict zoning regulations are imposed on some areas for urban containment (and not for farming purposes), they may increase urbanization pressure and the processes of land speculation in the surrounding farmlands where restrictions are less severe $[29,60]$.

Issues of spatial coherence have also been pointed out in programs of purchase of development rights (PDR). Lynch and Musser [61] showed that preserved parcels were scattered in Maryland. Such programs involve significant tradeoffs between preserving the most productive land (for sustaining the agricultural economy) and annexing the land that is most strategic for growth management policies $[62,63]$. This is especially significant when priority purchase areas are designated by local governments and/or nonprofit organizations [64]. On the urban fringe, voluntary FP instruments are not always sufficient to preserve the critical mass of farmland needed to sustain an agricultural industry [65]. With regard to achieving this goal, [66] stress the need to consider both the erosion of the farmland base and parcel fragmentation (parcel size and contiguity), because isolated parcels are less likely to remain actively farmed. To justify their public cost, PDR programs still have to demonstrate that they "not only prevent development, but truly help maintain farming" [67].

\subsection{Debates on the Impact of FP Programs on Farming on the Urban Fringe}

The impact of FP programs on farming has been widely debated. In the 1970s and 1980s, the "impermanence syndrome" was highlighted amongst farmers on the rural/urban fringe, who were reluctant to invest in farming because they expected agricultural decline and urban development $[68,69]$. Scholars compared alternative tools of FP [42,70]. In the 1990s, scholars underlined the positive effect of FP programs on preserving farming activities. Cases showed that strict regulations help avoid farmland fragmentation [2], while PDR enhances farms' economic viability by providing farmers with funds that can be invested in farm operations [71].

Since 2000, the effects of zoning and conservation easements on agricultural property values have been debated, but results of various econometric studies remain inconclusive [43,72]. Roe et al. [73] showed that preserved farmland provides an amenity for new residents that might attract new development in the surroundings. In their review, Bergstrom and Ready [74] conclude that public willingness to pay for farmland preservation in North America is positively related to farmland acreage, regional farmland scarcity, alternative development intensity, productivity (e.g., soil quality) and active farming, among others, and negatively related to intensive agriculture.

Several studies have examined how farming activity is affected by FP programs. Akimowicz et al. [75] highlight that Ontario's Greenbelt zoning is not sufficient to preserve urban-influenced farming. Lynch and Musser [61] showed that FP programs were most effective in maximizing the number of acres and preserving productive farms, rather than in preserving contiguous farms or threatened farms. Whether preserved farmland is falling out of agricultural use is still debated. FP may lead to a change in the way people farm: some concerns have emerged regarding the diversion of preserved farmland from agriculture to less intensive uses. In Oregon, strict regulations "may inadvertently encourage the growth of hobby farming, potentially at the expense of commercial farming" [38]. Brabec and Smith [66] also note a rise in equestrian pursuits and wildflower meadows taking "land out of traditional agriculture" in areas preserved by conservation easements and clustering programs. However, Gottlieb et al. [76] posit that the negative effect of hobby farming on urban fringe agriculture may be exaggerated: they find no evidence that hobby farmers are disproportionately attracted by voluntary farmland preservation programs and no statistically significant impact from FP on farm investment. For Schilling et al. [77], preserved farmland is even more likely to remain actively farmed. It attracts young farmers and incites owners to have succession plans to transfer the land to an active farmer.

In the Mediterranean, both trends of abandonment and intensification have been observed in peri-urban farmland under land-use regulations. In the hills above Florence, Italy, restrictive zoning 
aimed at preserving the historic landscape did not help retain farmers and active farming on the land [78]. Only wealthier landowners still maintain olive trees in their backyards, for aesthetic purposes. On the fringes of Barcelona, Spain, the Baix Llobregat Agricultural Park (BLAP) emerged as a farmers' initiative to preserve their farms and livelihoods [79]. This reinforced-zoning FP device was the impetus for sustainable intensification of existing farming and the development of local alternative food networks. Hence, though FP programs alone are often not enough to maintain active farming, they may be crucial to agricultural projects' success.

\subsection{Implementation Challenges Related to Public Action: A Lack of Coordination}

The scientific literature on FP reports many implementation issues related to the action of public stakeholders, especially for regulatory land-use planning.

Local authorities' interpretation of the legal framework often leads to spatial variations in the rules. This is mentioned in France [80], England [33], Switzerland [81] or the Netherlands [29]. Some authors further claim government failure. In Israel, Alfasi et al. [32] denounce case-by-case "discretionary-oriented decision-making, providing for revisions of the land-use plans and subsequently diminishing its efficacy", with FP being traded for economic growth. In Portugal, municipal master plans show high levels of non-compliance around Lisbon, mostly at the expense of peri-urban farmland [82]. In Italy, illegal building activities have been favored by the adoption of three building amnesty laws since 1984 [83]. But non-compliance with FP policies is not limited to the Mediterranean region [84]. In the US, Kline et al. [85] also document a "lack of adequate enforcement resulting in improper development mostly in exclusive agricultural use zones" in the Portland-Vancouver area. Since the 1980s, farmland preservation has often been analyzed as "a matter of local politics" [41,86], occasioning pressure on local officials by both development and conservation interests. Thus, it is not surprising that zoning decided at the local level appears to represent a political compromise [87].

To cope with implementation issues, planners and scholars stress the need for better vertical coordination between multiple decision levels $[5,88]$. Some authors fear negative effects on FP stemming from increased municipal autonomy [29] and believe that the solution lies in a supervisory authority [80,85]. However, Androkovich [24] shows that the supervisory commission which manages the agricultural land reserve of British Columbia, Canada, is also subject to pressure from development interests. The trade-off between restrictive top-down guidelines and local autonomy is still open to debate. In Mediterranean countries, the degree of local independence varies. Jouve and Napoléone [22] found that in 8 countries, local authorities (mainly at the municipal level) formulate their own land-use regulation policies and give building permits within the framework of national planning laws. The main tool used is exclusive agricultural zoning. In France and Italy, the current shift from a top-down management regime to a more decentralized and flexible one has, however, increased the complexity of governance [15]. Local authorities gain a lot of room to maneuver despite abiding by the common national legal framework. In Bavaria, Germany, Artmann [89] points out that flexibility—including informal planning strategies—sometimes acts as a guarantee of high acceptance and thus more effective implementation of FP policies by local authorities. Depending on the local context, local autonomy may thus attract criticism or praise for its potential to generate experimentation and innovation in FP.

Another implementation issue arises from the lack of horizontal coordination between sectoral policies. Farmland on the urban fringe is typically simultaneously at the heart of policies for urban planning, rural development, the environment and agriculture. The literature shows that a lack of intersectoral coordination increases low-density leapfrog urban development and the scattering of buildings related to farming. In Japan, the lack of coordination between the urban and the rural planning systems explains the disordered development patterns and increasing vacant areas in urban fringes [31]. In Switzerland, Gennaio et al. [81] identify conflicting goals and regulations with regard to farmland conservation and construction authorized for agricultural and rural development purposes in the Spatial Planning Law. Similar concerns about farm buildings are raised in other developed countries by Millward [90], Gosnell et al. [38] and Perrin et al. [15]. 
The Mediterranean is often pointed out as a region with a lack of enforcement of planning policies and a proliferation of illegal building practices. However, the above results underline that such issues occur in most countries.

\subsection{Differences in Time Frames and Uncertainty Discourage Farming on the Urban Fringe}

Conflicting time frames between long-term preservation programs and short-term individual strategies are additional barriers to maintaining active farming on the urban fringe.

A challenge of time frame adjustment is frequently mentioned for regulatory approaches. Uncertainty, speculation, and contradictory expectations are common within land-use planning processes [91]. Adelaja et al. [92] underline that the length of the planning horizon is directly related to the farm profile: farms with perennial crops, trees, or animals need longer-term planning horizons. In France, the economists Geniaux et al. [93] confirm that landowners' anticipation of agricultural land conversion is one of the key drivers of future development, especially when land-use plans are frequently altered or perceived as subject to change. Around Tokyo, where land prices are high, Yagi and Garrod [94] consider that a preferential taxation system may help farmers with real estate income to retain more of their farmland. Conflicting time frames between landowners' strategies, local authorities' political agenda and urgent urban development projects all create pressures leading to shorter farming leases. This in turn may discourage farming on the urban fringe and long-term farming investment.

Similarly, empirical studies dealing with negotiations on property rights (conservation easements, PDR) are united in stressing the issue of contradictory time frames among the parties and institutions involved. Because such programs are based on voluntary agreements, their efficacy may be weakened by individual landowners' strategies. Extensive literature has examined what motivates landowners to participate [95,96]. Lynch and Lovell [62] found that landowners closer to cities are less likely to participate, as did Comerford [97], who also stated that they are more likely to enroll for land that "they had already set aside for conservation, or land that is less suitable for production". Landowners may believe that placing an easement too soon could cause them to forego potential benefits in the future [98]. However, Towe et al. [99] found that the mere existence of an option to preserve farmland (through PDR) delays decisions to convert farmland for urban development.

\subsection{Farmland Protection Policies Must Be Adapted to Local Contexts}

The literature highlights the difficulty of assessing the efficacy of various tools and comparing case studies due to differences in social and spatial contexts. In particular, scholars warn against laying out possible causal relationships between land-use planning and land-use change [85]. Many exogenous and endogenous factors influence FP efficacy and land development patterns [100]. Our corpus of reviewed papers reveals three ranges of factors.

The first relates to geographic features such as existing population densities, urban growth patterns and physical land features, or socio-demographic determinants. For example, Altes [101] stresses that a tax on urban sprawl should distinguish between leapfrog and spill-over development patterns. Millward [90] finds more stringent control over urban sprawl in Great Britain and Japan than in Canada, yet puts his own results into perspective by stating that open space is a scarcer resource in the first two countries than in Canada. Previously around the Mediterranean, the typical urban settlement was very compact, with dynamic urban centers and numerous small and medium surrounding towns. But cities of the northern coast have all faced a sprawling expansion [102] while cities of the southern coast experienced more compact urban developments $[14,103]$. FP programs need to be adapted to such urban patterns.

The second range of factors relates to property rights regimes and land tenure. The right to compensation in the event of regulatory takings differs between countries [104,105]. Private property may be conceived as a bundle of rights or as full ownership. These differences help explain the growing interest in incentive- and market-based tools in the last twenty years in the US, while in Mediterranean countries, public policies 
do not usually feature conservation easement programs for FP. Public acquisitions are possible in France, Algeria, Greece or Tunisia, but in full ownership [22]. Also, in most Mediterranean countries, taxes on land ownership are low as the property structure is based on family lands, which are often considered more as a heritage than a production factor. Moreover, on both shores of the Mediterranean, political reforms tend to promote the private appropriation of farmland [14] and reduce the scope of the commons, whereas collective forms of land management prove to be resilient, especially in the case of extensive agro-pastoral systems or in order to promote local food supply chains [106]. The local diversity of land tenure in the Mediterranean has to be considered in FP policies, as well as the absence of comprehensive cadasters and the frequent fragmentation of land holdings or uneven land ownership structure. In Greece, these factors still contribute to the scattering of buildings on farmland, despite the recent implementation of municipal land-use regulations [107]. Farmers' land tenancy also counts: in the south of France and in Italy, land speculation comes from landowners, while tenant farmers will more actively support strict zoning regulations on the urban fringe [78].

The third range of factors relates to the local nature and dynamics of farming systems. Agriculture characteristics - such as relative agricultural profitability, local agricultural organizations, and the image of the agricultural sector-have a significant impact on the adoption of local FP policies [108]. In the French Provence, for instance, organic farming with high profitability appears to be an ally in the preservation of farmland on the urban fringe (ibid.). The same argument could be applied to highly profitable peri-urban farming systems based on vegetables or quality grapes growing around many southern European cities. However, FP policies have to acknowledge the diversity-and complexity - of the dynamics of farms in Mediterranean peri-urban settings [109]; the prime farmlands and farmers' requirements in terms of water access, minimum farmland size and collective facilities are not the same for vegetable as for grape growing [78]. The economic and social organization of farming also influences the ability to resist conversion of peri-urban farmland and the adoption of regulatory FP policies, as illustrated by the impressive development of short food supply chains in the agricultural park (BLAP) of Barcelona [79] or by the way a local union of Provençal wine producers successfully defended its terroir against urban expansion [110].

Different tools or policies may be needed or prioritized according to the local context. All the cited former barriers to FP, whether related to insufficient awareness concerning farming systems, to inadequate implementation by local authorities, or to the contradictory time frames among stakeholders, confirm that FP cannot rely on merely copy-pasting policy tools that have proved successful elsewhere.

\section{Improvement of Farmland Protection Policies and Future Research}

Recently identified avenues of improvement should help in designing FP strategies that take local contexts into account. Such strategies include technical innovations in spatial modeling, innovative participatory and collaborative approaches, non-financial means of compensation and combined tools.

\subsection{Integrating Social Data into Spatial Modeling}

Since 1995, new methods in spatial modeling have been developed. They may be considered revolutionary tools for policy-makers and comparative research. They are usually based on remote sensing, multi-criteria analysis, and Geographic Information Systems (GIS). These approaches address methodological issues identified in previous comparative approaches based mostly on statistical indicators or local maps [100]. They have been used to develop international comparative approaches of land-use changes [102] and to integrate environmental and human variables in strategic farmland characterization maps $[109,111]$.

Policy makers now count on such methods for diagnostic purposes in policy design to identify priority areas for intervention and context-specific public action opportunities [112], to assess FP policy implementation [38,63] with real-time monitoring [31], as well as to build prospective scenarios and sometimes to discuss trade-off options as part of participatory processes. Despite the 
sophistication of landscape modeling, scholars today stress the need to integrate more social data into such approaches; for instance, public perceptions and attitudes [113] or stakeholders' values and community knowledge [51]. In the case of the Huerta de Valencia, Marques-Perez and Segura [48] tested one method based on multi-criteria analysis to integrate social preferences for multifunctional peri-urban farming into planning processes. This constitutes an interesting research avenue connecting quantitative and qualitative geography with sociology and planning. Such improved spatial modeling would be especially relevant for some Mediterranean countries in which the state does not produce spatial data on farmland consumption. Specific funding, however, would be necessary to support local researchers' access to such tools and to aerial photos or satellite imagery.

\subsection{Involving Farmers and Recognizing Conflicting Points of View in Collaborative and Participatory Processes}

Stakeholder-based approaches like collaborative planning and participatory initiatives have become increasingly common when addressing complex policy issues.

However, implementing collaborative and participatory initiatives for FP is complex. The key issue is the diversity of stakeholders. Researchers state a lack of involvement of farmers [114]. The very different types of knowledge held by planners, elected officials and farmers can also make dialogue more difficult [115]. For example, James [116] blames the failure of green zones in Sydney on a lack of consultation with culturally and linguistically diverse small-scale farmers. Considering the role of expertise in FP task forces, Smith Korfmacher and Koontz [117] suggested that professionals work with collaborative groups to determine what information would be useful in the planning process.

Collaborative planning is also difficult because of stakeholders' conflicting points of view. State representatives often advocate urban containment, while local elected officials are often reluctant to counter urban development put forward by interest groups [118]. Another point of divergence relates to the various functions of peri-urban agriculture as defined by different stakeholders (economy, landscape, food, etc.) $[37,40]$. Around Toulouse (France), as well, Akimowicz et al. [75] stress the need for a better alignment of farmers and other agricultural stakeholders' representations of agriculture. Farmers themselves are not a homogeneous social category. They express diverse and sometimes divergent points of view according to their farming systems, age or land strategy $[60,116]$. Considering this diversity of farming styles may be another avenue of improvement for FP research and policy [106].

Building a consensus should not mean ignoring these conflicting points of view. It should instead acknowledge stakeholders' perceptions [51] and identify potential value conflicts [30]. Perceptions of injustice are pivotal aspects of land transactions [91]. To avoid the usual resentment toward planning processes, more research is needed on these issues of fairness and social acceptability of FP policies. This also means that planners and researchers could act less as regulators and more as productive mediators to achieve some form of consensus.

\subsection{Diversifying Compensation to Improve Social Acceptability}

FP issues illustrate how closely intertwined planning, laws and property rights may be. Restrictive zoning impacts property rights, but local negotiations on private rights also raise concerns about financial and non-financial considerations when landowners or tenants waive certain rights. A way to improve social acceptability of FP policies is to diversify types of compensation.

Monetary compensation can be used within collective farming goals, such as supporting land consolidation or collective processing units [30]. Non-monetary types of compensation can be used to overcome contradictory time frames and to avoid conflicting agendas (between local institutions in charge of preservation programs and landowners) and the speculative behavior that increases land prices. In the Netherlands, for instance, landowners are encouraged to demolish vacant buildings, especially empty stables, to improve the overall quality of the landscape. If they do, they receive new building rights [119]. This initiative, called the Space for Space Program, was set up following a European requirement to limit water pollution caused by nitrate emissions from the livestock industry. 
It represents a mixed model between the market-oriented programs of rights transfer currently used in the US and the regulatory instruments used in the planning-led European tradition.

In Spain, legal reforms have fostered the use of land readjustment to avoid financial compensation related to expropriations. In the Valencia region, land readjustment was used to create a new neighborhood. Landowners could choose between selling their property or receiving development rights in the adjusted land scheme [120]. The municipality received a portion of the land for infrastructures and public housing. However, such systems may foster urban sprawl. Land readjustment as a bottom-up initiative coordinated by developers may perpetuate local arrangements and prevent the adoption of restrictive planning regulations. Paradoxically, the strongest opponents to such land readjustment schemes turned out to be foreigners owning land in coastal areas, who protested against further urbanization and insufficient compensation. Conflicts arose especially in areas where rural property is very fragmented and where farm buildings were used illegally for residential purposes [121]. When non-financial compensation-a legal instrument initially designed to cope with a specific local issue-becomes a general planning strategy, it does not carry the same procedural guarantees (democratic control) as the more common land-use planning procedures.

Compensation—whether or not financial—should thus be combined with other tools.

\subsection{Combining Tools According to the Local Context}

While regulatory approaches since the 1960s have remained a topic of scientific interest, there has been a growing focus on incentive-based approaches and market-based instruments over the past twenty years.

These instruments do not work at the same scale in space and time. Zoning regulations protect a large area at limited public cost, but may trigger conflicts with landowners regarding compensation and be subject to renegotiation over time. Conservation easements are increasingly used in countries where zoning is considered a potential regulatory taking. They preserve smaller and not always contiguous areas for much longer periods of time, with some specific drawbacks such as the need to secure landowners' agreement, complexity and heavy implementation costs, etc. $[56,62,95,97]$. Conservation easements need to be coordinated and targeted at priority funding areas. Consequently, some scholars consider transferable development rights (TDR) as the cheapest way to pursue FP [66]. However, TDR programs are also complex to implement [122].

Thus, many authors conclude with a recommendation that FP tools should be combined. Open space protection policies work better when implemented in combination with compact urbanization strategies [6,118]. TDR and PDR programs can target the same area and reinforce one another in several ways [122]. Land preservation programs (PDR, TDR) can be based on tax incentives. In Lancaster County, Pennsylvania, such tools complement the widespread use of agricultural zoning and urban growth boundaries [65]. Planners and scholars advise combining these types of purchase programs with regional comprehensive land-use planning [71] and supportive zoning [64] for enhanced results.

Most success stories of farmland preservation thus combine tools within a long-term strategy. In the Dutch Green Heart for instance, the "success [of restrictive zoning] can be attributed to its rigidity and clarity, as well as to the use of additional instruments that for example help to purchase land and develop its recreational potential" [29]. However, while combining tools may appear as the soundest solution, stakeholders should remain aware that not all tools can be implemented in every context.

Further research — especially comparing detailed case studies—is thus needed to guide the choice and implementation of mixed-tool FP schemes in local contexts with diversified urban growth patterns, property rights regimes, or farming systems. This should be a fruitful research avenue for geographers working on Mediterranean countries.

\section{Conclusions}

The aim of this paper was to review the recent literature on the issue of farmland protection in the face of urbanization, with a specific focus on the Mediterranean region. This region is often pointed out 
as lacking effective planning policies while struggling with acute challenges related to food security. Yet, the literature underlines that issues related to FP policies are often the same across the world. Hence, our review of FP mechanisms in developed countries may bring valuable insights for more sustainable management of farmland on the urban fringe in the Mediterranean region.

This review highlights that FP cannot rely merely on transferring policy tools that have proven successful elsewhere. It also reveals that farming systems tend to be neglected by FP policies, as these often focus on land rather than on agriculture. FP policies do not always take into account the specific features of the local context and farmers' need for long-term guarantees if they are to invest and develop their activity on the urban fringe. Our review maps several interesting areas of research on the diversity of FP rationales, as well as the barriers and potential avenues for policy improvement. This may be of interest to students and scholars, but also to practitioners, policy makers and local groups looking for innovative, more flexible or locally suited farmland preservation programs.

Twenty years of research and practice have brought a greater understanding of the rationales behind FP. The literature shows that FP is underpinned, supported, and legitimized by disparate political and ethical views, ranging from urban containment and food security to environmentalist and agrarian ideologies. FP is not only motivated by a desire to support farming. Farming may be a means rather than an end in itself, and thus may become a tool to control urban growth and protect the environment and open spaces. These underlying rationales may change over time. They may also advocate for different farming styles (organic or conventional, commercial or hobby farming). Often, such rationales are not explicit because each position (for or against FP, for or against the use of some tools rather than others) is supported by coalitions of heterogeneous stakeholders with mixed interests. Local case studies revealing the underlying motivations and ethics of the stakeholders may suggest policy options that reduce land-use conflicts and help build a shared vision of the value and functions of farmland in the urban fringe. Research on FP rationales is thus a field that deserves renewed attention in sociology or social geography.

We identified recurrent barriers to implementation of FP policies: conflicting rationales, contradictory time frames, and failure to take into account diverse farming systems as well as the local context's unique features. The literature shows that the diversity of stakeholders' sometimes-contradictory perceptions generates resentment towards planning processes and may impede consensus building. However, researchers disagree on the need and the ways to involve local stakeholders and civil society in policy design. Some favor innovative collaborative or participatory approaches. Others stress the recurring risk of lobbying by economic, pro-development or NIMBY interests during implementation. Even when stakeholder participation is viewed as a cornerstone of policy legitimacy and success, researchers find that certain stakeholders, especially farmers, are often excluded from such processes. Farmers may lack the time or the skills to participate effectively in public policy debates. They are often not organized as a coherent social group with homogeneous strategies. Political ecology case studies could be developed to better understand the obstacles in achieving successful dialogue between state or local officials, landowners, developers, farmers, and non-farmer residents- each with their contradictory time frames, disparate ethical views and different types of knowledge.

We proposed further avenues of improvement of FP processes. Scholars should expose value conflicts and issues of fairness, especially in participatory and collaborative approaches. Planners and researchers together could act less as regulators and more as mediators of stakeholder groups to facilitate the coexistence of diverse value systems and agriculture models on the urban fringe and to help identify conflicting opinions before seeking a consensus. This is an opportunity for action-research. Our review also reveals a growing connection between the qualitative literature dealing with local implementation challenges of FP policies and applied literature dealing with land-use change modeling for diagnosis, monitoring, assessment, or prospective purposes. One of the current challenges in this field is to integrate more social data into spatial modeling, but this can only be tackled by interdisciplinary research teams. Finally, our review reveals a growing debate on methods of compensation for FP or urbanization. Here again, critical sociology or social geography approaches 
could help unravel the issues of social and spatial justice among various stakeholders, while planners and economists might be more interested in reframing individual compensation within collective goals.

Since the effects of FP programs are incremental and occur over long periods of time, they are difficult to measure. Now that FP policies have been in place for years in several Mediterranean countries, detailed comparative case studies are needed to determine how the toolbox has been adapted to each local context. While more international comparison would be useful-either to examine country-specific characteristics or the use of certain policy tools across various conditions/factors-our review highlights a greater need for more comprehensive interdisciplinary inquiries at the local level in order to reveal how social, spatial, political and economic contexts affect the design and successful implementation of FP policies.

Finally, this review has been centered on planning issues and land policies, but in developed countries, preserving farmland and maintaining farming on the urban fringe are now frequent features of more holistic, cross-sectoral territorial policies in which peri-urban agriculture is valued as multifunctional and as a provider of ecosystemic services and public goods [57]. Research is still needed to understand how these new framings (for instance through urban food strategies [123,124], agro-ecosystems [20] or productive landscapes [125]), may help to design innovative planning instruments, more in line with the emerging needs of urban and peri-urban farmers, as well as city dwellers.

Author Contributions: All four authors have made substantial contributions to the conception of the work. They all contributed to the analysis and interpretation of data; they collectively wrote the original draft; they approved the submitted version and agree to be personally accountable for the accuracy and integrity of any part of the work. Conceptualization, Methodology, Formal Analysis, Data Curation, Writing-Original Draft Preparation, C.P., C.C., R.M., B.N.; Writing-Review \& Editing, C.P.; Supervision, C.P.; Project Administration, C.P.; Funding Acquisition, C.P. All authors have read and agreed to the published version of the manuscript.

Funding: The authors received financial support from the French National Research Agency under the program JASMINN Anr-14-CE18-0001.

Acknowledgments: We especially thank Harvey M. Jacobs for his helpful comments on a prior version of this paper. This paper also benefited from the discussion that followed its presentation at the 10th annual conference of the International Academic Association on Planning, Law and Property rights.

Conflicts of Interest: The authors declare no conflict of interest

\section{References}

1. Bryant, C.R.; Johnston, T.R.R. Agriculture in the City's Countryside; University of Toronto Press: Toronto, Buffalo, 1992.

2. Nelson, A.C. Preserving Prime Farmland in the Face of Urbanization: Lessons from Oregon. J. Am. Plan. Assoc. 1992, 58, 467-488. [CrossRef]

3. Bren d'Amour, C.; Reitsma, F.; Baiocchi, G.; Barthel, S.; Güneralp, B.; Erb, K.H.; Haberl, H.; Creutzig, F.; Seto, K.C. Future Urban Land Expansion and Implications for Global Croplands. Proc. Natl. Acad. Sci. USA 2017, 114, 8939-8944. [CrossRef] [PubMed]

4. Tan, R.; Beckmann, V.; van den Berg, L.; Qu, F. Governing Farmland Conversion: Comparing China with the Netherlands and Germany. Land Use Policy 2009, 26, 961-974. [CrossRef]

5. Bengston, D.N.; Fletcher, J.O.; Nelson, K.C. Public Policies for Managing Urban Growth and Protecting Open Space: Policy Instruments and Lessons Learned in the United States. Landsc. Urban Plan. 2004, 69, 271-286. [CrossRef]

6. Alterman, R. The Challenge of Farmland Preservation: Lessons from a Six-Nation Comparison. J. Am. Plan. Assoc. 1997, 63, 220-243. [CrossRef]

7. Hirt, S. Mixed Use by Default How the Europeans (Don't) Zone. J. Plan. Lit. 2012, 27, 375-393. [CrossRef]

8. Duke, J.M.; Lynch, L. Farmland Retention Techniques: Property Rights Implications and Comparative Evaluation. Land Econ. 2006, 82, 189-213. [CrossRef]

9. Lichtenberg, E.; Ding, C. Assessing Farmland Protection Policy in China. Land Use Policy 2008, 25, 59-68. [CrossRef] 
10. Wang, H.; Tao, R.; Wang, L.; Su, F. Farmland Preservation and Land Development Rights Trading in Zhejiang, China. Habitat Int. 2010, 34, 454-463. [CrossRef]

11. Ceccarelli, T.; Bajocco, S.; Perini, L.; Salvati, L. Urbanisation and Land Take of High Quality Agricultural Soils-Exploring Long-Term Land Use Changes and Land Capability in Northern Italy. Int. J. Environ. Res. 2014, 8, 181-192. [CrossRef]

12. Perrin, C. Un Littoral Sans Nature? L'avenir de la Méditerranée Face à l'urbanisation; École française de Rome: Rome, Italy, 2013.

13. Cuadrado-Ciuraneta, S.; Durà-Guimerà, A.; Salvati, L. Not Only Tourism: Unravelling Suburbanization, Second-Home Expansion and "Rural" Sprawl in Catalonia, Spain. Urban Geogr. 2017, 38, 66-89. [CrossRef]

14. Debolini, M.; Valette, E.; François, M.; Chéry, J.P. Mapping land use competition in the rural-urban fringe and future perspectives on land policies: A case study of Meknès (Morocco). Land Use Policy 2015, 47, 373-381. [CrossRef]

15. Perrin, C.; Nougarèdes, B.; Sini, L.; Branduini, P.; Salvati, L. Governance Changes in Peri-Urban Farmland Protection Following Decentralisation: A Comparison between Montpellier (France) and Rome (Italy). Land Use Policy 2018, 70, 535-546. [CrossRef]

16. Lteif, C.; Soulard, C.T. L'agriculture urbaine à Beyrouth, Liban: Quel rôle du foncier waqf? Rives Méditerranéennes 2019, 59, 183-205. [CrossRef]

17. Grasso, M.; Feola, G. Mediterranean Agriculture under Climate Change: Adaptive Capacity, Adaptation, and Ethics. Reg. Environ. Chang. 2012, 12, 607-618. [CrossRef]

18. Debolini, M.; Marraccini, E.; Dubeuf, J.P.; Geijzendorffer, I.R.; Guerra, C.; Simon, M.; Targetti, S.; Napoléone, C. Land and Farming System Dynamics and Their Drivers in the Mediterranean Basin. Land Use Policy 2018, 75, 702-710. [CrossRef]

19. Henke, R.; Vanni, F. Drivers of on-farm diversification in the Italian peri-urban agriculture. Ital. Rev. Agric. Econ. 2017, 72, 79-100. [CrossRef]

20. Soulard, C.T.; Valette, E.; Perrin, C.; Abrantes, P.C.; Anthopoulou, T.; Benjaballah, O.; Bouchemal, S.; Dugué, P.; Amrani, M.E.; Lardon, S.; et al. Peri-Urban Agro-Ecosystems in the Mediterranean: Diversity, Dynamics, and Drivers. Reg. Environ. Chang. 2017, 18, 1-12. [CrossRef]

21. Soulard, C.T.; Perrin, C.; Valette, E. Relations Between Agriculture and the City in Europe and the Mediterranean. In Toward Sustainable Relations Between Agriculture and the City, Urban Agriculture; Soulard, C.-T., Perrin, C., Valette, E., Eds.; Springer International Publishing: Cham, Switzerland, 2017; pp. 1-11. [CrossRef]

22. Jouve, A.M.; Napoléone, C. Modes de Régulation de l'usage Des Terres En Méditerranée et Protection Des Terres Agricoles. Options Méditerranéennes 2011, 66, 9-21.

23. Gardner, B.D. The Economics of Agricultural Land Preservation. Am. J. Agric. Econ. 1977, 59, $1027-1036$. [CrossRef]

24. Androkovich, R.A. British Columbia's Agricultural Land Reserve: Economic, Legal and Political Issues. Land Use Policy 2013, 30, 365-372. [CrossRef]

25. Mualam, N. Playing with Supertankers: Centralization in Land Use Planning in Israel-A National Experiment Underway. Land Use Policy 2018, 75, 269-283. [CrossRef]

26. Kline, J.; Wichelns, D. Public Preferences Regarding the Goals of Farmland Preservation Programs. Land Econ. 1996, 72, 538-549. [CrossRef]

27. Maruani, T.; Amit-Cohen, I. Open Space Planning Models: A Review of Approaches and Methods. Landsc. Urban Plan. 2007, 81, 1-13. [CrossRef]

28. Brédif, H.; Pupin, V. Réévaluer La Place de l'agriculture à l'heure Du Grand Paris. Annales de Géographie 2012, 683, 43-65. [CrossRef]

29. Koomen, E.; Dekkers, J.; van Dijk, T. Open-Space Preservation in the Netherlands: Planning, Practice and Prospects. Land Use Policy 2008, 25, 361-377. [CrossRef]

30. Kerselaers, E.; Rogge, E.; Vanempten, E.; Lauwers, L.; Van Huylenbroeck, G. Changing Land Use in the Countryside: Stakeholders' Perception of the Ongoing Rural Planning Processes in Flanders. Land Use Policy 2013, 32, 197-206. [CrossRef]

31. Saizen, I.; Mizuno, K.; Kobayashi, S. Effects of Land-Use Master Plans in the Metropolitan Fringe of Japan. Landsc. Urban Plan. 2006, 78, 411-421. [CrossRef]

32. Alfasi, N.; Almagor, J.; Benenson, I. The Actual Impact of Comprehensive Land-Use Plans: Insights from High Resolution Observations. Land Use Policy 2012, 29, 862-877. [CrossRef] 
33. Gant, R.L.; Robinson, G.M.; Fazal, S. Land-Use Change in the 'Edgelands': Policies and Pressures in London's Rural-Urban Fringe. Land Use Policy 2011, 28, 266-279. [CrossRef]

34. Amati, M.; Yokohari, M. Temporal Changes and Local Variations in the Functions of London's Green Belt. Landsc. Urban Plan. 2006, 75, 125-142. [CrossRef]

35. Feitelson, E. Social Norms, Rationales and Policies: Reframing Farmland Protection in Israel. J. Rural Stud. 1999, 15, 431-446. [CrossRef]

36. Spaling, H.; Wood, J.R. Greed, Need or Creed? Farmland Ethics in the Rural-Urban Fringe. Land Use Policy 1998, 15, 105-118. [CrossRef]

37. Bunce, M. Thirty Years of Farmland Preservation in North America: Discourses and Ideologies of a Movement. J. Rural Stud. 1998, 14, 233-247. [CrossRef]

38. Gosnell, H.; Kline, J.D.; Chrostek, G.; Duncan, J. Is Oregon's Land Use Planning Program Conserving Forest and Farm Land? A Review of the Evidence. Land Use Policy 2011, 28, 185-192. [CrossRef]

39. Mariola, M.J. Losing Ground: Farmland Preservation, Economic Utilitarianism, and the Erosion of the Agrarian Ideal. Agric. Hum. Values 2005, 22, 209-223. [CrossRef]

40. Bills, N.; Gross, D. Sustaining Multifunctional Agricultural Landscapes: Comparing Stakeholder Perspectives in New York (US) and England (UK). Land Use Policy 2005, 22, 313-321. [CrossRef]

41. Renard, V. Plans D'urbanisme et Justice Foncière; Presses Universitaires de France: Paris, France, 1980.

42. Jacobs, H.M. Social Equity in Agricultural Land Protection. Landsc. Urban Plan. 1989, 17, 21-33. [CrossRef]

43. Liu, X.; Lynch, L. Do Zoning Regulations Rob Rural Landowners' Equity? Am. J. Agric. Econ. 2011, 93, 1-25. [CrossRef]

44. Bryant, C.R. The Role of Local Actors in Transforming the Urban Fringe. J. Rural Stud. 1995, 11, $255-267$. [CrossRef]

45. Torre, A.; Traversac, J.B.; Darly, S.; Melot, R. Paris, métropole agricole ? Quelles productions agricoles pour quels modes d'occupation des sols. Revue d'Économie Régionale Urbaine 2013, 3, 561-593. [CrossRef]

46. Dunk, A.; von der Grêt-Regamey, A.; Dalang, T.; Hersperger, A.M. Defining a Typology of Peri-Urban Land-Use Conflicts - A Case Study from Switzerland. Landsc. Urban Plan. 2011, 101, 149-156. [CrossRef]

47. Pacione, M. Private Profit, Public Interest and Land Use Planning-A Conflict Interpretation of Residential Development Pressure in Glasgow's Rural-Urban Fringe. Land Use Policy 2013, 32, 61-77. [CrossRef]

48. Marques-Perez, I.; Segura, B. Integrating social preferences analysis for multifunctional peri-urban farming in planning. An application by multi-criteria analysis techniques and stakeholders. Agroecol. Sustain. Food Syst. 2018, 42, 1029-1057. [CrossRef]

49. Melot, R.; Paoli, J.C. Espaces protégés, espaces sanctuarisés ? Conflits autour de la loi littoral en Corse. Économie Rural. 2012, 332, 60-73. [CrossRef]

50. Lokocz, E.; Ryan, R.L.; Sadler, A.J. Motivations for Land Protection and Stewardship: Exploring Place Attachment and Rural Landscape Character in Massachusetts. Landsc. Urban Plan. 2011, 99, 65-76. [CrossRef]

51. Fitzsimons, J.; Pearson, C.J.; Lawson, C.; Hill, M.J. Evaluation of Land-Use Planning in Greenbelts Based on Intrinsic Characteristics and Stakeholder Values. Landsc. Urban Plan. 2012, 106, 23-34. [CrossRef]

52. Ives, C.D.; Kendal, D. Values and Attitudes of the Urban Public towards Peri-Urban Agricultural Land. Land Use Policy 2013, 34, 80-90. [CrossRef]

53. Kline, J.; Wichelns, D. Public Preferences Regarding the Goals of Farmland Preservation Programs: Reply. Land Econ. 1998, 74, 566-569. [CrossRef]

54. Brinkley, C. Evaluating the Benefits of Peri-Urban Agriculture. J. Plan. Lit. 2012, 27, 259-269. [CrossRef]

55. Kerselaers, E.; Rogge, E.; Dessein, J.; Lauwers, L.; Van Huylenbroeck, G. Prioritising Land to Be Preserved for Agriculture: A Context-Specific Value Tree. Land Use Policy 2011, 28, 219-226. [CrossRef]

56. Duke, J.M. Participation in Agricultural Land Preservation Programs: Parcel Quality and a Complex Policy Environment. Agric. Resour. Econ. Rev. 2004, 33, 34-49. [CrossRef]

57. Piorr, A.; Zasada, I.; Doernberg, A.; Zoll, F.; Ramme, W. Research for AGRI Committee-Urban and Peri-urban Agriculture in the EU, European Parliament, Policy Department for Structural and Cohesion Policies, Brussels. 2018. Available online: https://www.europarl.europa.eu/RegData/etudes/STUD/2018/617468/IPOL_ STU(2018)617468_EN.pdf (accessed on 8 July 2020).

58. Balestrat, M.; Barbe, É.; Chery, J.P.; Lagacherie, P.; Tonneau, J.P. Reconnaissance du patrimoine agronomique des sols: Une démarche novatrice en Languedoc-Roussillon. Norois 2011, 221, 83-96. [CrossRef] 
59. Diaz, D.; Green, G.P. Growth Management and Agriculture: An Examination of Local Efforts to Manage Growth and Preserve Farmland in Wisconsin Cities, Villages, and Towns. Rural Sociol. 2001, 66, 317-341. [CrossRef]

60. Serrano, J.; Vianey, G. Patrimonialiser des activités agricoles pour banaliser la consommation d'espaces agricoles périurbains: Réflexions à partir du cas de l'agglomération de Tours. Géographie économie société 2014, 16, 297-314.

61. Lynch, L.; Musser, W.N. A Relative Efficiency Analysis of Farmland Preservation Programs. Land Econ. 2001, 77, 577-594. [CrossRef]

62. Lynch, L.; Lovell, S.J. Combining spatial and survey data to explain participation in agricultural land preservation programs. Land Econ. 2003, 79, 259-276. [CrossRef]

63. Stoms, D.M.; Jantz, P.A.; Davis, F.W.; DeAngelo, G. Strategic Targeting of Agricultural Conservation Easements as a Growth Management Tool. Land Use Policy 2009, 26, 1149-1161. [CrossRef]

64. Lewis, R.; Knaap, G.J. Targeting Spending for Land Conservation an Evaluation of Maryland's Rural Legacy Program. J. Am. Plan. Assoc. 2012, 78, 34-52. [CrossRef]

65. Daniels, T.; Lapping, M. Land Preservation: An Essential Ingredient in Smart Growth. J. Plan. Lit. 2005, 19, 316-329. [CrossRef]

66. Brabec, E.; Smith, C. Agricultural Land Fragmentation: The Spatial Effects of Three Land Protection Strategies in the Eastern United States. Landsc. Urban Plan. 2002, 58, 255-268. [CrossRef]

67. Maynard, L.J.; Kelsey, T.W.; Lembeck, S.M.; Becker, J.C. Early Experience with Pennsylvania's Agricultural Conservation Easement Program. J. Soil Water Conserv. 1998, 53, 106-112.

68. Berry, D. Effects of Urbanization on Agricultural Activities. Growth Chang. 1978, 9, 2-8. [CrossRef]

69. Lopez, R.A.; Adelaja, A.O.; Andrews, M.S. The Effects of Suburbanization on Agriculture. Am. J. Agric. Econ. 1988, 70, 346-358. [CrossRef]

70. Rickard, T.J. Problems in Implementing Farmland Preservation Policies in Connecticut. J. Rural Stud. 1986, 2, 197-207. [CrossRef]

71. Pfeffer, M.J.; Lapping, M.B. Farmland Preservation, Development Rights and the Theory of the Growth Machine: The Views of Planners. J. Rural Stud. 1994, 10, 233-248. [CrossRef]

72. Nickerson, C.J.; Lynch, L. The Effect of Farmland Preservation Programs on Farmland Prices. Am. J. Agric. Econ. 2001, 83, 341-351. [CrossRef]

73. Roe, B.; Irwin, E.G.; Morrow-Jones, H.A. The Effects of Farmland, Farmland Preservation, and Other Neighborhood Amenities on Housing Values and Residential Growth. Land Econ. 2004, 80, 55-75. [CrossRef]

74. Bergstrom, J.C.; Ready, R.C. What Have We Learned from over 20 Years of Farmland Amenity Valuation Research in North America? Rev. Agric. Econ. 2009, 31, 21-49. [CrossRef]

75. Akimowicz, M.; Kephaliacos, C.; Landman, K.; Cummings, H. Planning for the future? The emergence of shared visions for agriculture in the urban-influenced Ontario's Greenbelt, Canada, and Toulouse InterSCoT, France. Reg. Envir. Chang. 2020, 20, 57. [CrossRef]

76. Gottlieb, P.D.; Schilling, B.J.; Sullivan, K.; Esseks, J.D.; Lynch, L.; Duke, J.M. Are Preserved Farms Actively Engaged in Agriculture and Conservation? Land Use Policy 2015, 45, 103-116. [CrossRef]

77. Schilling, B.J.; Esseks, J.D.; Duke, J.M.; Gottlieb, P.D.; Lynch, L. The Future of Preserved Farmland: Ownership Succession in Three Mid-Atlantic States. J. Agric. Food Syst. Community Dev. 2016, 5, 129-153. [CrossRef]

78. Perrin, C. Regulation of Farmland Conversion on the Urban Fringe: From Land-Use Planning to Food Strategies. Insight into Two Case Studies in Provence and Tuscany. Int. Plan. Studies 2013, 18, 21-36. [CrossRef]

79. Paül, V.; McKenzie, F.H. Peri-Urban Farmland Conservation and Development of Alternative Food Networks: Insights from a Case-Study Area in Metropolitan Barcelona (Catalonia, Spain). Land Use Policy 2013, 30, 94-105. [CrossRef]

80. Serrano, J. Quel équilibre entre urbanisation et préservation des espaces agricoles périurbains ? Le cas d'une agglomération moyenne. Développement durable et Territoires 2005, 4, 1-11. [CrossRef]

81. Gennaio, M.P.; Hersperger, A.M.; Bürgi, M. Containing Urban Sprawl—Evaluating Effectiveness of Urban Growth Boundaries Set by the Swiss Land Use Plan. Land Use Policy 2009, 26, 224-232. [CrossRef]

82. Abrantes, P.; Fontes, I.; Gomes, E.; Rocha, J. Compliance of Land Cover Changes with Municipal Land Use Planning: Evidence from the Lisbon Metropolitan Region (1990-2007). Land Use Policy 2016, 51, 120-134. [CrossRef] 
83. Falco, E. Protection of coastal areas in Italy: Where do national landscape and urban planning legislation fail? Land Use Policy 2017, 66, 80-89. [CrossRef]

84. Calor, I.; Alterman, R. When Enforcement Fails: Comparative Analysis of the Legal and Planning Responses to Non-Compliant Development in Two Advanced-Economy Countries. Int. J. Law Built Environ. 2017, 9, 207-239. [CrossRef]

85. Kline, J.D.; Thiers, P.; Ozawa, C.P.; Alan Yeakley, J.; Gordon, S.N. How Well Has Land-Use Planning Worked under Different Governance Regimes? A Case Study in the Portland, OR-Vancouver, WA Metropolitan Area, USA. Landsc. Urban Plan. 2014, 131, 51-63. [CrossRef]

86. Schiffman, I. Saving California Farmland: The Politics of Preservation. Landsc. Plan. 1983, 9, 249-269. [CrossRef]

87. Senecal, G.; Hamel, P.J.; Guerpillon, L.; Boivin, J. Aménager la métropole nature: Retour sur les efforts passés de planification dans la région de Montréal et essai d'évaluation de la situation actuelle des banlieues. Géocarrefou 2001, 76, 303-317. [CrossRef]

88. Clément, C.; Abrantes, P. Préserver les espaces agricoles périurbains face à l'étalement urbain. Une problématique locale? Norois 2011, 221, 67-82. [CrossRef]

89. Artmann, M. Institutional Efficiency of Urban Soil Sealing Management-From Raising Awareness to Better Implementation of Sustainable Development in Germany. Landsc. Urban Plan. 2014, 131, 83-95. [CrossRef]

90. Millward, H. Urban Containment Strategies: A Case-Study Appraisal of Plans and Policies in Japanese, British, and Canadian Cities. Land Use Policy 2006, 23, 473-485. [CrossRef]

91. Holtslag-Broekhof, S.M.; Beunen, R.; van Marwijk, R.; Wiskerke, J.S.C. "Let's Try to Get the Best out of It" Understanding Land Transactions during Land Use Change. Land Use Policy 2014, 41, 561-570. [CrossRef]

92. Adelaja, A.; Sullivan, K.; Hailu, Y.G. Endogenizing the Planning Horizon in Urban Fringe Agriculture. Land Use Policy 2011, 28, 66-75. [CrossRef]

93. Geniaux, G.; Ay, J.-S.; Napoléone, C. A Spatial Hedonic Approach on Land Use Change Anticipations. J. Reg. Sci. 2011, 51, 967-986. [CrossRef]

94. Yagi, H.; Garrod, G. The future of agriculture in the shrinking suburbs: The impact of real estate income and housing costs. Land Use Policy 2018, 76, 812-822. [CrossRef]

95. Miller, A.D.; Bastian, C.T.; McLeod, D.M.; Keske, C.M.; Hoag, D.L. Factors Impacting Agricultural Landowners' Willingness to Enter into Conservation Easements: A Case Study. Soc. Nat. Resour. 2010, 24, 65-74. [CrossRef]

96. Frondel, M.; Lehmann, P.; Wätzold, F. The Impact of Information on Landowners' Participation in Voluntary Conservation Programs-Theoretical Considerations and Empirical Evidence from an Agri-Environment Program in Saxony, Germany. Land Use Policy 2012, 29, 388-394. [CrossRef]

97. Comerford, E. The impact of permanent protection on cost and participation in a conservation programme: A case study from Queensland. Land Use Policy 2013, 34, 176-182. [CrossRef]

98. Cross, J.E.; Keske, C.M.; Lacy, M.G.; Hoag, D.L.K.; Bastian, C.T. Adoption of Conservation Easements among Agricultural Landowners in Colorado and Wyoming: The Role of Economic Dependence and Sense of Place. Landsc. Urban Plan. 2011, 101, 75-83. [CrossRef]

99. Towe, C.; Nickerson, C.; Bockstael, N. An empirical examination of the timingof land conversions in the presence of farmland preservation programs. Am. J. Agric. Econ. 2008, 90, 613-626. [CrossRef]

100. Kline, J.D. Comparing States with and without Growth Management Analysis Based on Indicators with Policy Implications Comment. Land Use Policy 2000, 17, 349-355. [CrossRef]

101. Altes, W.K.K. Taxing Land for Urban Containment: Reflections on a Dutch Debate. Land Use Policy 2009, 26, 233-241. [CrossRef]

102. Salvati, L. Urban Containment in Action? Long-Term Dynamics of Self-Contained Urban Growth in Compact and Dispersed Regions of Southern Europe. Land Use Policy 2013, 35, 213-225. [CrossRef]

103. Marraccini, E.; Debolini, M.; Moulery, M.; Abrantes, P.; Bouchier, A.; Chéry, J.P.; Sanz Sanz, E.; Sabbatini, T.; Napoleone, C. Common Features and Different Trajectories of Land Cover Changes in Six Western Mediterranean Urban Regions. Appl. Geogr. 2015, 62, 347-356. [CrossRef]

104. Dissart, J.C. Protection des espaces agricoles et naturels: Une analyse des outils américains et français. Économie Rural. 2006, 291, 6-25. [CrossRef]

105. Jacobs, H.M. The Future of the Regulatory Takings Issue in the United States and Europe: Divergence or Convergence? Urban Lawyer 2008, 40, 51-72.

106. Baysse-Lainé, A.; Perrin, C. How Can Alternative Farmland Management Styles Favour Local Food Supply? A Case Study in the Larzac (France). Land Use Policy 2018, 75, 746-756. [CrossRef] 
107. Nikolaidou, S. Politiques de Planification et Logiques Des Acteurs Locaux Dans Le Contexte de Périurbanisation Du Sud-Est d'Athènes. Options Méditerranéennes 2011, 66, 145-157.

108. Chanel, O.; Delattre, L.; Napoleone, C. Determinants of Local Public Policies for Farmland Preservation and Urban Expansion: A French Illustration. Land Econ. 2014, 90, 411-433. [CrossRef]

109. Sanz Sanz, E.; Martinetti, D.; Napoléone, C. Operational Modelling of Peri-Urban Farmland for Public Action in Mediterranean Context. Land Use Policy 2018, 75, 757-771. [CrossRef]

110. Minvielle, P.; Carroll, É.; Daligaux, J. Le patrimoine foncier comme marqueur des relations identitaires au terroir, l'exemple du vignoble de Bandol. Sud-Ouest Européen 2013, 29-40. [CrossRef]

111. Schmidt, E.; Thorne, J.; Huber, P.; Roth, N.; Thompson, E.; McCoy, M. A New Method Is Used to Evaluate the Strategic Value of Fresno County Farmland. Calif. Agric. 2010, 64, 129-134. [CrossRef]

112. Tassinari, P.; Torreggiani, D.; Benni, S. Dealing with Agriculture, Environment and Landscape in Spatial Planning: A Discussion about the Italian Case Study. Land Use Policy 2013, 30, 739-747. [CrossRef]

113. Ryan, R.L. The Social Landscape of Planning: Integrating Social and Perceptual Research with Spatial Planning Information. Landsc. Urban Plan. 2011, 100, 361-363. [CrossRef]

114. Duvernoy, I.; Barthe, L.; Lima, S. Les représentations de l'activité agricole dans les projets de territoires périurbains: Exemple de trois Pays en Midi-Pyrénées. Norois 2013, 224, 49-60. [CrossRef]

115. Jarrige, F.; Thinon, P.; Nougarèdes, B. La Prise En Compte de l'agriculture Dans Les Nouveaux Projets de Territoires Urbains. Exemple d'une Recherche En Partenariat Avec La Communauté d'Agglomération de Montpellier. Revue d'Économie Régionale Urbaine 2006, 3, 393-414. [CrossRef]

116. James, S.W. Protecting Sydney's Peri-Urban Agriculture: Moving beyond a Housing/Farming Dichotomy. Geogr. Res. 2014, 52, 377-386. [CrossRef]

117. Smith Korfmacher, K.; Koontz, T.M. Collaboration, Information, and Preservation: The Role of Expertise in Farmland Preservation Task Forces. Policy Sci. 2003, 36, 213-236. [CrossRef]

118. Nelson, A.C.; Moore, T. Assessing Growth Management Policy Implementation: Case Study of the United States' Leading Growth Management State. Land Use Policy 1996, 13, 241-259. [CrossRef]

119. Janssen-Jansen, L.B. Space for Space, a Transferable Development Rights Initiative for Changing the Dutch Landscape. Landsc. Urban Plan. 2008, 87, 192-200. [CrossRef]

120. Veen, M.; van der Spaans, M.; Janssen-Jansen, L. Using Compensation Instruments as a Vehicle to Improve Spatial Planning: Challenges and Opportunities. Land Use Policy 2010, 27, 1010-1017. [CrossRef]

121. Blanc, F. Spain: Non-Financial Compensation Instruments and the Valencia Model. In New Instruments in Spatial Planning: An International Perspective on Non-Financial Planning; Janssen-Jansen, L., Spaans, M., van der Veen, M., Eds.; IOS Press: Amsterdam, The Netherlands, 2008; pp. 95-120.

122. Kaplowitz, M.D.; Machemer, P.; Pruetz, R. Planners' Experiences in Managing Growth Using Transferable Development Rights (TDR) in the United States. Land Use Policy 2008, 25, 378-387. [CrossRef]

123. Moragues-Faus, A.; Morgan, K. Reframing the foodscape: The emergent world of urban food policy. Environ. Plan. A Econ. Space 2015, 47, 1558-1573. [CrossRef]

124. Brand, C.; Bricas, N.; Conare, D.; Daviron, B.; Debru, J.; Michel, L.; Soulard, C.T. (Eds.) Designing Urban Food Policies: Concepts and Approaches, Urban Agriculture; Springer International Publishing: Cham, Switzerland, 2019.

125. Viljoen, A.; Bohn, K. Second Nature Urban Agriculture: Designing Productive Cities; Routledge: London, UK, 2014.

(C) 2020 by the authors. Licensee MDPI, Basel, Switzerland. This article is an open access article distributed under the terms and conditions of the Creative Commons Attribution (CC BY) license (http://creativecommons.org/licenses/by/4.0/). 